\title{
Workplace violence
}

\section{A threat to autonomy and professional discretion}

\begin{abstract}
Although many theories have been developed and a great amount of research has been conducted on autonomy and professional discretion, knowledge on the extent to which fear of being subjected to workplace violence might restrict such autonomy and professional discretion being used is limited. This article draws on a survey study $(\mathrm{N}=1,236)$ and compares the experiences of workplace violence of Swedish social workers, teachers and journalists. The aim of the article is to determine how digitalisation could be linked to workplace violence and also determine the extent to which workplace violence could affect the autonomy and professional discretion of these professional groups and prevent them from carrying out their democratic role. The results show the differences regarding where and how these professionals received threats and provides an alarming picture of the implications of such threats. $40 \%$ of the respondents had considered stopping working on a specific social problem, topic, target group, or task due to their fear of being subjected to hate, threats and harassment.
\end{abstract}

Keywords: journalists, professional discretion, social workers, teachers, workplace violence, democracy

WORKPLACE VIOLENCE IS a widely acknowledged issue. Historically, only physical assaults and homicide have been perceived as workplace violence, However, with start in the 1990s there has been a major shift and in many countries the definition of workplace violence has been expanded to include hate, threats and harassment (see e.g. Cole, Grubb, Sauter et al. 1997; Journalistpanelen 2016; Löfgren Nilsson \& Örnebring 2016). Workplace violence can include both verbal abuse (e.g. threats, derogatory remarks) and physical abuse (e.g. kicking, beating up, pushing, spitting). However, it is sometimes difficult to define what is considered to be hate, threats and harassment because the same situation can be perceived differently by different people. In the workplace and in various professions, different cultures and standards have presumably been developed concerning the kinds of behaviour that individuals are expected to tolerate. In some workplaces and professions, a certain amount of workplace violence or hate, threats and harassment might be considered as being "part of the job" (e.g. Respass \& Payne 2008), while other workplaces would have a zero-tolerance policy towards such behaviour (e.g. Wikman \& Rickfors 2017). There is an ongoing dis- 
cussion in the Nordic countries about the importance of not normalising workplace violence but finding ways of preventing it. Studies show that some professions are subjected to workplace violence more than others (Patel \& Holmberg 2015; Swedish Work Environment Authority 2018) and that workplace violence has increased in recent years (Heiskanen 2007; Jerre 2009; Wikman 2016; Frenzel 2017).

As working life has become increasingly digitalised, where and how people are subjected to threats has also changed and it has become increasingly important to address the extent to which professional groups receive digital threats and whether such threats differ from the "traditional" forms of workplace violence (see e.g. Rayner \& Cooper 2006; Forssell 2016 regarding cyberbullying). Today, many individuals carry their "offices" in their pockets or in their bags because many work-related tools are accessible on smartphones, tablets and laptops, enabling interaction with managers, colleagues and target groups (e.g. clients, pupils and their families, readers) online (cf. Muhonen, Jönsson \& Bäckström 2017). Organisations have become more accessible and due to technology, the threshold of gaining access to professionals such as social workers, teachers and journalists has been lowered (cf. Patel \& Holmberg 2015; Scaramuzzino forthcoming). This means that people outside an organisation can easily post threatening messages on social media, thereby affecting an organisation's work environment. It has been argued that it is important to address hate, threats and harassment that occur in different arenas in order to gain a comprehensive picture of contemporary workplace violence (cf. Scaramuzzino \& Scaramuzzino forthcoming). It is also important to explore the extent to which digitalisation might be linked to workplace violence.

It is widely acknowledged that workplace violence is a serious issue although less is known about the extent to which workplace violence could actually affect autonomy and professional discretion, thereby preventing certain groups of professionals from carrying out their democratic roles. Theories have been developed and previous research has been conducted into how the fear of being harassed and attacked can discourage journalists from exercising their role as watchdogs of democracy (see e.g. Waisbord 2013; Yesil 2014; Journalistpanelen 2016; Löfgren Nilsson \& Örnebring 2016; Tandoc 2017; Hughes \& Márquez-Ramírez 2018; Kargar \& Rauchfleisch 2019). However, less is known about how hate, threats and harassment affect the autonomy and discretion of other professional groups that also have an important democratic role to play (see e.g. Lundquist 1998).

This article is based on a survey study $(\mathrm{N}=1,236)$ and compares Swedish social workers', teachers' and journalists' experiences of hate, threats and harassment as forms of workplace violence. The study on which this article is based focuses on the respondents' own experiences of workplace violence and no distinction is made between the three types of violence (i.e. hate, threats and harassment). Waddington, Badger and Bull (2006) argue that such an inclusive definition of workplace violence might be problematic as it could create "moral panic" when verbal and physical abuse are given equal status. However, when studying the professional groups' own experiences of workplace violence, a broad and inclusive definition, such as the definition used in this study, 
can actually be useful (Waddington, Badger \& Bull 2006). Physical assaults do not necessarily have more of a negative impact on victims than verbal abuse (Waddington, Badger \& Bull 2005). The study introduces distinctions between where hate, threats or harassment occurred (although physical abuse is not possible through digital media) and between various consequences of workplace violence.

The aim of this article is twofold. First, to determine how digitalisation could be linked to workplace violence. Second, to determine the extent to which workplace violence could affect autonomy and professional discretion and to address the similarities and differences between the three groups of professionals regarding these matters.

In this article, the following three research questions will be answered:

1. To what extent are social workers, teachers and journalists exposed to workplace violence?

2. How is digitalisation linked to the three professional groups' exposure to workplace violence?

3. To what extent does workplace violence affect the autonomy and discretion of the three professional groups?

The analysis focuses on comparing the extent to which these three phenomena (exposure, digitalisation and the effect of workplace violence) occur among three professional groups.

\section{Three professional groups with a democratic role}

The three professional groups compared in this article were selected because of their democratic roles. Social workers are responsible for the welfare of vulnerable groups; teachers have a major responsibility for shaping new generations of citizens; and journalists have a watchdog role. Second, these groups of professionals often occupy positions of power in society. Social workers work in human service organisations and can provide both access to and withhold resources and services. By exercising their authority, they can also affect their clients' lives using coercive measures such as taking children into custody. Teachers also work in human service organisations and their assessment of the achievements of children and young people can significantly impact their future lives. Journalists can influence the issues that are put on the agenda and how they are communicated to the public. Third, these groups of professionals are often "frontline workers" although they work with different target groups. Social workers primarily work with individuals in the context of occasional meetings, as well as with young people with special needs. Teachers work with pupils and students on a daily basis and can be expected to be subjected to workplace violence resulting from situations involving individual pupils or students. Journalists have a more public profile and work towards a wider audience - the public - and could therefore be more exposed to threats and violence in the digital realm.

What is common to these groups of professionals is that in recent years, trade unions, 
NGOs, employees, employers and researchers - both in Sweden and globally - have expressed serious concern because these professionals are being subjected to increasing workplace violence (see e.g. Respass \& Payne 2008; Koritsas, Coles \& Boyle 2010; Novus \& Union for Professionals 2016; Winstanley \& Hales 2015 for social workers; Human Rights Watch 2010; Göransson, Knight, Guthenberg et al. 2011 for teachers; Löfgren Nilsson 2015, 2017; Tandoc 2017 for journalists), although they have seldom been compared to each other in this regard (see Waddington, Badger \& Bull 2005, 2006 for a comparison between police officers and social care professionals). A comparison between the above-mentioned groups of professionals could provide important insights into general and specific patterns of workplace violence, as well as how such violence affects their autonomy and professional discretion. Because of their fear of being victimised, social workers, teachers and journalists might stop working on certain social problems or target groups, might hesitate to assign grades, or might stop covering certain topics of interest and expressing their views (cf. Journalistpanelen 2016). This represents a significant threat to democracy (Eggebø \& Stubberud 2016; Scaramuzzino forthcoming).

\section{Previous research and theoretical perspectives}

This section focuses on previous research and the theoretical perspectives upon which this article draws. This article aims to contribute to theories on autonomy, professional discretion and self-censorship, as well as to research on workplace violence. Extensive research has been conducted on these topics and it therefore cannot be fully presented here. The focus of this article is on previous research on social workers, teachers and journalists and includes the following areas that are of importance for the aim of this article: 1) where and how these professionals are exposed to workplace violence, and 2) their autonomy, professional discretion and practices of self-censorship.

\section{Where and how}

Having reviewed previous studies on workplace violence, it appears that where and how professionals receive threats differs depending on the type of profession (Patel $\&$ Holmberg 2015; AFA Insurance 2018a). Professions that involve significant interaction with other people, so-called 'frontline workers' (Almond \& Gray 2016), are clearly more exposed to threats and violence than other professions (Heiskanen 2007; AFA Insurance 2018b), as well as professional groups that are active in the public debate and that work with public opinion (Scaramuzzino forthcoming).

A number of Swedish studies have been conducted on workplace violence against different groups of professionals and most of these studies show that online hate speech has increased over the last decade (Swedish Union of Journalists 2009; Göransson, Knight, Guthenberg et al. 2011; Löfgren Nilsson 2015; Novus \& Union for Professionals 2016; see Journalistpanelen 2016 for an exception). One study shows that e-mail was the most common form of communication for cyberbullying in working life (Forssell 2016). However, according to other studies, social workers primarily receive threats via telephone calls, e-mails or letters (AFA Insurance 2018a). Teachers often receive 
threats and are subjected to violence at school when students became frustrated, had been told what to do, or when teachers intervened when students were fighting (AFA Insurance 2018a). About one half of teachers had witnessed a pupil at school breaking something or losing control of their behaviour (Göransson, Knight, Guthenberg et al. 2011). Being subjected to physical violence was rare and only $1 \%$ of women and $3 \%$ of men had been subjected to physical violence in their professional roles as teachers. Verbal abuse was more common and was reported by around 20\% of women and $15 \%$ of men. Around $28 \%$ of teachers had been subjected to so-called cyber violence, and men and women had been equally subjected to this kind of violence (ibid.).

Regarding journalists, studies from the Nordic countries show that face to face threats seldom occur and, unlike social workers and teachers, journalists do not often interact with their target groups face to face (cf. Patel \& Holmberg 2015). The most common way that journalists were threatened was via e-mail (see e.g. Journalistpanelen 2016; Löfgren Nilsson \& Örnebring 2016), telephone and social media. In one study, 20\% of journalists reported receiving threats via e-mail and $15 \%$ had received threats via social media, telephone or through comments on articles that they had written (Journalistpanelen 2016). The journalists received offensive remarks through the same communication channels as they received threats, the common being e-mail (53\%) and social media (42\%). In comparison with a study conducted in 2012, there were no major changes regarding the frequency of threats against Swedish journalists or how such threats were received. However, derogatory remarks had decreased (from $49 \%$ to 36\%) and the way in which they were communicated had changed. Since 2012, many newspapers have changed the way they work and have developed strategies to prevent hate speech, for example, by moderating threads on social media more strictly or even closing down the comment fields (ibid.). Thus, research has been conducted on hate, threats and harassment through digital media, although much of the focus has been on the consequences on an individual level, not on a professional level. Thus, less is known about the association between workplace violence, digitalisation and autonomy, professional discretion and self-censorship.

\section{Autonomy, professional discretion and self-censorship}

Many theories have been developed and a great amount of previous research has been conducted on autonomy, professional discretion and self-censorship. Evetts (2002:341) writes: "Professional workers have been characterized as having autonomy both in respect of their professional judgements and decision making, and in respect of their immunity from regulation or evaluation by others". Social work, teaching and journalism are self-regulating occupations as they involve formalised education and training and sometimes require professional licenses. Some professions have self-governing bodies that specifically work to restrict state interventions. These provisions give the professions and the respective professionals both legitimacy and authority to govern themselves and professionals are given a certain degree of freedom from external control (Evetts 2002; Waisbord 2013). Freidson (1994) makes an important distinction between collective and individual autonomy. The online surveys upon which this article is based focus on the experiences of social workers, teachers and journalists, i.e. 
autonomy on an individual level, although restricted individual autonomy can have also implications for the collective institutional autonomy of the respective profession.

Professionals can also use professional discretion - the freedom to work in a professional role (Evans 2013, 2020) - and this can be regarded as being the most important aspect of decision-making and professional judgment. Professional discretion has both a cognitive and a social aspect in the sense that discretion entails both a reasoning and a space in which the professional is given the autonomy to decide and act according to their own judgment (Molander, Grimen \& Eriksen 2012).

Regarding welfare professionals, there has been much focus on how external control, such as laws, regulations, economic measures (i.e. increasing costs and limited financial resources) and higher demands on administration can limit their autonomy. For example, in social work there is much literature about how discretion is structured in different organisational and political contexts (Brodkin 2020) and the focus has been on the tensions between professional freedom and organisational rules and how different policies and structures restrict professional freedom. The focus has also been on how welfare professionals have a "social rights role" and have to make decisions regarding who gets what, how and when they get it, as well as who gets heard. This means that excessive professional discretion can be a threat to the democratic control of the decision-making ability of professionals (Molander, Grimen \& Eriksen 2012; Fitzpatrick, McKeever \& Simpson 2019; Brodkin 2020). Because of the lack of transparency, social workers' autonomy has sometimes been compared to a "black box" (Svensson, Johnsson \& Laanemets 2008:79), that is a system comprising visible inputs and outputs but opaque internal mechanisms. However, there has been less focus on the extent to which other types of external control such as hate, threats and harassment could affect the discretion and autonomy of welfare professionals as part of their democratic role.

Regarding professional groups, most of the focus has been on journalists because of their role as "watchdogs" and defenders of free speech. Autonomy has been described as a core ideal of journalism because it requires autonomy to achieve its democratic goals (Waisbord 2013:43). Scholars have primarily focused on how authoritarian regimes attempt to curb free speech and suppress and control critical voices, often through social media (see e.g. Kargar \& Rauchfleisch 2019 for the situation in Iran) and how this also occurs in instable democracies or "democracies and authoritarian hybrids" involving, for example, widespread corruption and organised crime (see e.g. Hughes \& Márquez-Ramírez 2018 for a description of the situation in Mexico) and in "young democracies" (see e.g. Tandoc 2017 for a description of the situation in the Philippines). Löfgren Nilsson (2017), who has conducted several studies on the situation of journalists in Sweden, described how studies on journalists' situations in democratic countries are rare, even though intimidation and harassment of journalists by actors other than the state can also result in different kinds of adjustments and self-censoring (see also Löfgren Nilsson \& Örnebring 2016). Research (e.g. Journalistpanelen 2016) shows that the fear of being harassed and attacked can affect the ability of journalists to exercise their role as watchdogs. In fact, Tandoc (2017) states that it is important to "watch over" the watchdogs. Scholars (e.g. Yesil 2014; Crawford \& Hutchinson 2015; 
Kargar \& Rauchfleisch 2019) have discussed how different self-censoring practices pose a serious threat to the future of independent journalism.

Previous research (Journalistpanelen 2016; see also Löfgren Nilsson \& Örnebring 2016) shows that harassment of Swedish journalists is common and that around three in ten journalists had refrained from monitoring certain issues or groups/individuals due to the risk of being harassed or threatened. The risk of being exposed to offensive remarks also resulted in self-censorship and around two in ten journalists had stopped monitoring certain issues or groups/individuals due to the risk of receiving offensive remarks. One study (Göransson, Knight, Guthenberg et al. 2011) shows that teachers who had been subjected to hate speech and violence the most wanted to leave their jobs compared to teachers who had not been subjected to such hate speech and violence (cf. also Shier, Graham \& Nicholas 2018 for social workers). Another study (Journalistpanelen 2016) shows that about one in seven (16\%) journalists considered changing their job due to the risk of receiving threats. If groups of professionals who have an important role to play in democratic society change the ways in which they work or hesitate to make a decision or write an article, societal trust in these professionals could decrease (cf. Wallström, Korsell \& Andersson 2009) and it could stop people from joining the profession (Tandoc 2017). This strand of research has not focused much on how digitalisation could influence autonomy and professional discretion.

This article seeks to contribute to existing research by comparing three groups of professionals and showing the similarities and differences in their experiences (see also Waddington, Badger \& Bull 2005, 2006). The article also explores how digitalisation could be linked to workplace violence and the extent to which workplace violence could affect autonomy and professional discretion, which has largely been ignored in previous theories and research on welfare professionals and journalists.

\section{Method and data}

\section{Data collection and sample}

This article is based on data gathered from an online survey study that was conducted using the survey tool Sunet Survey between October 2018 and January 2019. A total of 1,236 respondents responded to the three online surveys. All the respondents were members of three unions in Sweden: the Union for Professionals (Akademikerförbun$\operatorname{det}$ SSR $)^{1}$, the Swedish Teachers' Union (Lärarförbundet) ${ }^{2}$ and the Swedish Union of Journalists (Journalistförbundet) ${ }^{3}$. These unions were selected because they are responsible for organising most of these groups of professionals in Sweden.

1 The Union for Professionals has approximately 72,000 members (Union for Professionals 2019).

2 The Swedish Teachers' Union has approximately 234,000 members (Swedish Teachers' Union 2019).

3 The Swedish Union of Journalists has approximately 15,000 members (Swedish Union of Journalists 2019). 
It was not possible to use the identical sampling process for the three groups of professionals as the three unions interpreted the provisions and implications of the General Data Protection Regulation differently, the latter of which had recently been introduced. The social workers and journalists were notified about the survey two weeks in advance in order to give them sufficient time to ask questions and opt out from the study. Two of the unions sent an e-mail with a link to the online survey, followed by reminders (two to journalists and three to social workers). The Union for Professionals organises academics with a degree in social science, behavioural science or social work. Thus, only social workers and people working in social work were included in the sample. The Swedish Union of Journalists used a tool called EditNews to send e-mails to its members. Job seekers and members who were on leave of absence, were not included in the sample, i.e. only members who were currently working were included.

The online survey sent to the teachers followed a different procedure. The Swedish Teachers' Union used its own survey system to distribute information about the study and the link to the online survey. A message with information about the study was sent to a random sample of union members asking them if they wanted to participate in the study. The members who accepted the invitation received a link to the online survey. The sample size and response rate for the three professional groups are shown in Table 1.

Table 1. Sample size and response rate

\begin{tabular}{lrrr} 
& Social workers & Journalists & Teachers \\
\hline Sample (e-mails sent) & 2,500 & 2,254 & $\begin{array}{r}8,000 \\
\text { (with information } \\
\text { about the survey) }\end{array}$ \\
$\begin{array}{l}\text { Participants (who } \\
\text { accepted the invitation) }\end{array}$ & & & 854 \\
E-mail 'bounces' & 111 & 1 & 474 \\
Respondents & 523 & $11 \%$ & $\begin{array}{r}6 \% \text { (of sample) } \\
\text { Response rate }\end{array}$ \\
& $22 \%$ & & $56 \%$ (of participants) \\
\hline
\end{tabular}

Scholars have discussed how online surveys often have lower response rates than paper surveys. However, this does not imply that online surveys are less representative, per se (Fynboe, Huibers, Christensen et al. 2018). In order to examine how representative the populations were, despite the low response rates, I performed a drop-out analysis by comparing the union's statistics on its members with some background information ${ }^{4}$

4 Gender, age and type of sector (social workers), type of school (teachers), and type of media (journalists). 
about the respondents in the online surveys. One of the unions did not consent to the exact numbers of its members being published, so this information cannot be included here. However, the drop-out analysis shows that there was no major bias regarding the representativeness of either social workers, journalists or teachers.

\section{Survey questions}

This article is based on seven survey questions. The table in the appendix shows the exact wording of the survey questions, which questions relate to which research questions and the response alternatives provided in the surveys. In order to answer the first research question (RQ1) about the extent to which professional groups are exposed to workplace violence, there were three survey questions. One multiple choice question comprising 15 potential response alternatives covered the second research question (RQ2): how digitalisation is liked to professional groups being subject to workplace violence. In order to make a clearer comparison in the analysis between the various professions, the 15 different response alternatives ${ }^{5}$ were merged into three. ${ }^{6}$ In order to answer the third research question (RQ3), three examples were provided of how autonomy and discretion could be limited. These were inspired by the survey study by Löfgren Nilsson and Örnebring (2016) on the intimidation and harassment of Swedish journalists and its consequences.

\section{Analysis}

The analysis was performed using SPSS and compared the responses from the respondents based on the professional group to which they belonged. Hence, the unit of analysis was not individuals but professional groups, thereby allowing the diversity of conditions and experiences to be shown. The data were analysed using bivariate analyses that tested the association between the respondents' responses and their respective profession. In the analysis I used Cramer's V, which is often used as a measure of association in cross-tabulation between nominal variables, giving a value between 0 and 1. The value 0 represents no association and the value 1 represents complete association.

\section{Results}

Regarding the results of the study, a survey question asked about whether the respondents had ever been exposed to hate, threats or harassment in their professional role. See Table 2.

5 Face to face, travelling between work and home, or vice versa, phone call, SMS/MMS, letter or postcard, e-mail, internet forum, blog, Facebook, Twitter, Instagram, YouTube, LinkedIn, receiving a product that had not been ordered, being recorded or photographed without consent.

6 Face to face, phone/SMS/MMS, internet and social media. 
Table 2. Have you ever been exposed to hate, threats or harassment in your professional role? (\%)

\begin{tabular}{lrrrr}
$\begin{array}{l}\text { Have you ever been exposed to } \\
\text { hate, threats or harassment in your } \\
\text { professional role? }\end{array}$ & $\begin{array}{r}\text { Social } \\
\text { workers }\end{array}$ & Teachers & Journalists & $\begin{array}{r}\text { \% of all } \\
\text { professionals }\end{array}$ \\
\hline Yes & 74.3 & 53.5 & 61.1 & 63.8 \\
No & 25.7 & 46.6 & 38.9 & 36.2 \\
Total N & 522 & 473 & 239 & 1,234 \\
\hline
\end{tabular}

Cramer's V $=0.196^{* * *}$, Significance: $\dagger=10 \%,{ }^{*}=5 \%,{ }^{* *}=1 \%,{ }^{* * *}=0.1 \%$

More than three in five respondents responded "yes" to the question of whether they had ever been exposed to hate, threats or harassment in their professional role. There were significant differences between the professional groups concerning the extent to which they had been subjected to workplace violence. As shown in Table 2, three in four social workers had been exposed to workplace violence, followed by $61 \%$ of journalists and around one half of teachers. When comparing these groups of professionals, it becomes clear that social workers were subjected to workplace violence the most, journalists were in between and teachers were subjected to the least amount of workplace violence. Focusing on the question of how often the respondents had received hate, threats or harassment over the last two years, a slightly different picture emerged. See Table 3.

Table 3. Frequency of received hate, threats or harassment over the last two years (\%)

\begin{tabular}{lrrrr}
$\begin{array}{l}\text { Over the last two years, how often } \\
\text { have you received hate, threats or } \\
\text { harassment in your professional role? }\end{array}$ & $\begin{array}{r}\text { Social } \\
\text { workers }\end{array}$ & Teachers & Journalists & $\begin{array}{r}\text { \% of all } \\
\text { professionals }\end{array}$ \\
\hline Never & 34.6 & 26.5 & 21.9 & 29.6 \\
Sometimes every six months & 55 & 43.1 & 57.5 & 51.7 \\
Sometimes every month & 8.8 & 17.8 & 16.4 & 13.1 \\
Sometimes every week & 1.3 & 10.3 & 4.1 & 4.7 \\
Every day & 0.3 & 2.4 & 0 & 0.9 \\
Total N & 387 & 253 & 146 & 786 \\
\hline
\end{tabular}

Cramer's V $=0.194^{* * *}$, Significance: $\dagger=10 \%,{ }^{*}=5 \%,{ }^{* *}=1 \%,{ }^{* * *}=0.1 \%$

As Table 3 shows, fewer respondents responded to this question ( $N=786$ instead of $\mathrm{N}=1,234$ ) because the respondents who stated that they had never been exposed to workplace violence in the previous question were not asked the second question in the 
survey. There were also significant differences between the professional groups and the frequency of workplace violence. Even though social workers have been subjected the most to workplace violence (as shown in the previous table), such incidents had not occurred as frequently over the last two years as they had for teachers and journalists. In fact, most of the respondents who responded "yes" to the first question had received hate, threats or harassment "sometimes every 6 months". However, 18\% of teachers and $16 \%$ of journalists stated that they had received hate, threats or harassment "sometimes every month" and as many as one in ten teachers had received hate, threats or harassment "sometimes every week" over the last two years. When studying this table, it is clear that teachers received the most hate, threats or harassment over the last two years, journalists were in between and social workers had received the least amount of hate, threats or harassment.

To determine whether these were "just" empty threats, the survey included a third question about whether the threats the professionals had received had been carried out. The question did not allow the respondents to specifically state what the threats were about (e.g. violence in the workplace, on private property or in person) but whether or not the threats had been carried out. The rationale here is that whether it was common for the threats to be carried out, no matter what kind of threat, they would probably affect the victim more. See Table 4.

Table 4. Frequency of threats being carried out (\%)

\begin{tabular}{lllll}
$\begin{array}{l}\text { Over the last two years, have the } \\
\text { threats you have received been } \\
\text { carried out? }\end{array}$ & $\begin{array}{l}\text { Social } \\
\text { workers }\end{array}$ & Teachers & Journalists & $\begin{array}{l}\text { \% of all } \\
\text { professionals }\end{array}$ \\
\hline Yes, often or always & 0.8 & 0.5 & 0 & 0.6 \\
Yes, sometimes & 2.4 & 10.4 & 2.7 & 5.2 \\
Yes, but rarely & 8.1 & 20.3 & 3.6 & 11.3 \\
No, never & 88.7 & 68.7 & 93.8 & 83 \\
Total N & 248 & 182 & 112 & 542 \\
\hline
\end{tabular}

Cramer's V $=0.202^{* * *}$ Significance: $\dagger=10 \%,{ }^{*}=5 \%,{ }^{* *}=1 \%,{ }^{* * *}=0.1 \%$

There were also significant differences between professional groups and the frequency of the threats being carried out. The association here was stronger than in the previous two questions. A total of 542 respondents responded to this question. As the table shows, $94 \%$ of threats directed at journalists and $89 \%$ of threats directed at social workers had never been carried out. The teachers faced a rather different situation. One in five teachers had experienced threats being carried out, although this rarely happened. One in ten teachers had experienced it occasionally. Thus, by studying the frequency of the threats being carried out, it is clear that teachers most often expe- 
rienced the threats being carried out, social workers were in between and journalists experienced this the least. These figures may reflect how these groups of professionals work and how close they are to their target groups. However, they also reflect the people with whom they interact. Teachers work with children and young persons and in the case of very young children, certain types of violence tend to be more common as the children have not fully learnt how to deal with and express their emotions (cf. Göransson, Knight, Guthenberg et al. 2011).

\section{Journalists are subjected to the most digital hate, threats and harassment}

Previous research (cf. Muhonen, Jönsson \& Bäckström 2017; Scaramuzzino forthcoming) has highlighted that the use of the internet and social media has changed the relationship of professionals with their target groups. Most work organisations have a website, Facebook page, Twitter account and Instagram account, and many professionals use the internet and social media in their work to communicate with their clients or target groups. Thus, the focus will now shift to the question of where and how the hate, threats and harassment were received over the last two years. See Table 5.

Table 5. Where the hate, threats, and harassment occurred (\%)

\begin{tabular}{lrrrrrr} 
& $\begin{array}{r}\text { Social } \\
\text { workers }\end{array}$ & Teachers & $\begin{array}{r}\text { Jour- } \\
\text { nalists }\end{array}$ & $\begin{array}{r}\text { \% of all } \\
\text { professionals }\end{array}$ & $\begin{array}{r}\text { Number of } \\
\text { analysed cases }\end{array}$ & Cramer's V \\
\hline Face to face & 70.4 & 87.6 & 23 & 66.2 & 541 & $0.495^{* * *}$ \\
Phone/SMS/MMS & 63.2 & 19.1 & 38.1 & 43.4 & 541 & $0.394^{* * *}$ \\
$\begin{array}{l}\text { Internet and social } \\
\text { media }\end{array}$ & 30.8 & 19.7 & 92.9 & 40.1 & 541 & $0.563^{* * *}$ \\
\hline
\end{tabular}

Significance: $\dagger=10 \%,{ }^{*}=5 \%,{ }^{* *}=1 \%,{ }^{* *}=0.1 \%$

As Table 5 shows, there were significant differences between professional groups and where the hate, threats or harassment had occurred - and the association is strong. $88 \%$ of teachers and $70 \%$ of social workers who had received hate, threats and harassment had experienced this face to face (and travelling between work and home, or vice versa). The comparison between professional groups also showed that journalists clearly differed from the other groups in this respect. Only 23\% of journalists had received hate, threats or harassment in this way. Focusing on telephone threats (including SMS/ MMS), a slightly different picture emerges. In this case, $63 \%$ of social workers had received telephone threats followed by $38 \%$ of journalists and $19 \%$ of teachers. It is clear that social workers received the most telephone threats, journalists were in between and teachers received the least number of telephone threats. Focusing on threats via the internet and social media (e-mail, Facebook, internet forums, blogs, Twitter, Instagram, YouTube, LinkedIn), an entirely different picture emerges again: $93 \%$ of 
journalists, $31 \%$ of social workers and $20 \%$ of teachers had been exposed to workplace violence through these communication channels. The results suggest that digitalisation adds communication channels for workplace violence to the existing channels, and this is particularly true for journalists.

In order to establish whether digitalisation is linked to professionals being subjected to workplace violence, it is important to look more closely at hate, threats and harassment on the internet and social media. See Table 6.

Table 6. Percentage of professional subjected to hate, threats and harassment through different internet and social media channels

\begin{tabular}{lrrrrrr} 
& $\begin{array}{r}\text { Social } \\
\text { workers }\end{array}$ & Teachers & $\begin{array}{r}\text { Jour- } \\
\text { nalists }\end{array}$ & $\begin{array}{r}\text { \% of all } \\
\text { professionals }\end{array}$ & $\begin{array}{r}\text { Number of } \\
\text { analysed cases }\end{array}$ & Cramer's V \\
\hline E-mail & 28.4 & 16.9 & 69 & 33.1 & 541 & $0.407^{* * *}$ \\
Facebook & 4.8 & 3.9 & 38.9 & 11.6 & 541 & $0.437^{* * *}$ \\
Internet forum & 2.4 & 1.7 & 27.4 & 7.4 & 541 & $0.394^{* * *}$ \\
Twitter & 0 & 0.6 & 18.6 & 4.1 & 541 & $0.378^{* * *}$ \\
Blog & 0.4 & 0 & 9.7 & 2.2 & 541 & $0.263^{* * *}$ \\
\hline
\end{tabular}

Significance: $\dagger=10 \%,{ }^{*}=5 \%,{ }^{* *}=1 \%,{ }^{* * *}=0.1 \%$

As Table 6 shows, there are also significant differences between professional groups and receiving hate, threats or harassment through all the communication channels that have been studied. The association between the variables is also strong here. In fact, looking more closely at the data, two main results emerge. First, it is evident that e-mail was the most common communication channel. Second, journalists were subjected to hate, threats or harassment more than the other professions through these communication channels. These results confirm the results of previous studies (see e.g. Patel \& Holmberg 2015; Journalistpanelen 2016; Löfgren Nilsson \& Öhrnebring 2016).

These results are perhaps not surprising because they could reflect the way in which these groups of professionals work, interact with their target groups and the closeness of their relationship with their target groups (see also Patel \& Holmberg 2015; AFA Insurance 2018b). In fact, teachers interact with their pupils face to face in the classroom. Social workers also often interact their clients face to face in social services, hospitals, schools or other organisations in which they practice their profession. However, they often use the telephone to interact with their clients. Journalists may not interact with their target groups face to face in the same way as the other two groups of professionals as they tend to interact with their target groups via e-mail. Unlike social workers and teachers, journalists are usually not personally acquainted with the people with whom they interact, for example, their readers. This potentially makes them an easier target for anonymous hate messages, threats and harassment. 
Overall, the results suggest that digitalisation is linked to professionals being subjected to workplace violence, although this is most evident for journalists. It could be asked whether these results reflect the different degrees of digitalisation of the work environments of these groups of professionals. This will be further discussed in the conclusions and discussion.

\section{Autonomy, professional discretion and self-censorship}

The following section discusses the implications of workplace violence for these groups of professionals and, in particular, how their fear of being subjected to hate, threats or harassment had affected the respondents' work. See Table 7.

Table 7. Implications, percentage of professionals who responded positively ("yes") to the questions

\begin{tabular}{|c|c|c|c|c|c|c|}
\hline & $\begin{array}{r}\text { Social } \\
\text { workers }\end{array}$ & Teachers & $\begin{array}{r}\text { Jour- } \\
\text { nalists }\end{array}$ & $\begin{array}{c}\% \text { of all } \\
\text { profes- } \\
\text { sionals }\end{array}$ & $\begin{array}{r}\text { Number of } \\
\text { analysed } \\
\text { cases }\end{array}$ & $\begin{array}{r}\text { Cramer's } \\
\mathrm{V}\end{array}$ \\
\hline $\begin{array}{l}\text { Have you ever changed } \\
\text { your way of working } \\
\text { due to your fear of being } \\
\text { exposed to hate, threats } \\
\text { or harassment? }\end{array}$ & 59.1 & 66.9 & 72.5 & 64.2 & 486 & $0.106 \dagger$ \\
\hline $\begin{array}{l}\text { Have you ever considered } \\
\text { stopping working on a } \\
\text { specific social problem/ } \\
\text { topic/target group/task } \\
\text { due to your fear of being } \\
\text { exposed to hate, threats } \\
\text { or harassment? }\end{array}$ & 44.9 & 28.2 & 53.8 & 40.1 & 486 & $0.198^{* * *}$ \\
\hline $\begin{array}{l}\text { Have you ever considered } \\
\text { leaving your job due } \\
\text { to your fear of being } \\
\text { exposed to hate, threats } \\
\text { or harassment? }\end{array}$ & 36.4 & 42 & 11.3 & 34.4 & 486 & $0.222^{* * *}$ \\
\hline
\end{tabular}

Significance: $\dagger=10 \%,{ }^{*}=5 \%,{ }^{* *}=1 \%,{ }^{* *}=0.1 \%$

Looking at the overall picture, 64\% of the respondents had changed their way of working due to their fear of being exposed to workplace violence. Almost three in four journalists $(73 \%)$ had changed the way they worked, followed by teachers $(70 \%)$ and social workers (59\%). However, the association between the responses to this question and the professions is weak. As the table illustrates, more than half of the journalists $(54 \%)$ had considered stopping working on a specific social problem/topic/ 
target group/task due to their fear of being exposed to workplace violence, followed by social workers (45\%) and teachers (28\%).

A previous study on Swedish journalists showed that more than $30 \%$ of journalists had refrained from monitoring certain issues or groups/individuals due to the risk of being threatened (Journalistpanelen 2016). However, the figures in the present survey are much higher. In fact, journalist who were subjected to the greatest amount of digital hate, threats and harassment had also limited their autonomy and professional discretion to a higher extent because of their fear of being exposed to workplace violence.

Around one in three of the respondents had considered leaving their jobs because of their fear of being exposed to workplace violence. Even though the figures are high for journalists regarding the previous two survey questions, only $11 \%$ of journalists had considered leaving their jobs. The figures are much higher for teachers (42\%) and social workers (36\%). The figures for journalists were much higher regarding whether they had ever changed the way they worked and had ever considered stopping working on a specific social problem/topic/target group. The figures for teachers were higher regarding whether they had ever considered leaving their job because of their fear of being exposed to workplace violence. Looking at the overall picture, it would appear that the fear of being subjected to hate, threats or harassment does indeed potentially affect both the autonomy and the discretion of these professional groups.

\section{Conclusions and discussion}

The table below summarises the findings and the comparisons between the professional groups.

Table 8. Overview of the comparison of the professional groups

\begin{tabular}{lccc} 
& Social workers & Teachers & Journalists \\
\hline Exposure level & Greatest & Least & In between \\
Frequency & Least & Greatest & In between \\
Threats being carried out & In between & Greatest & Least \\
Digital impact & In between & Least & Greatest \\
$\begin{array}{l}\text { Changed your way of } \\
\text { working }\end{array}$ & Least & In between & Greatest \\
$\begin{array}{l}\text { Stopped working on a } \\
\text { specific social problem/ } \\
\text { topic/target group/task }\end{array}$ & In between & Least & Greatest \\
Leaving your job & In between & Greatest & Least \\
\hline
\end{tabular}


This article shows that the three professional groups being compared had different experiences of workplace violence. The results suggest that the where professional groups receive hate, threats or harassment is closely linked to where they meet and communicate with their target groups and the social distance from the groups with which they interact. Teachers often received threats face to face, social workers face to face or over the telephone and journalists via the internet and social media. These results suggest that the more professionals use digital media to interact with their target groups, the more hate, threats and harassment they will receive through such channels. In Sweden there is strong political pressure on the welfare services to become increasingly digitalised (see e.g. Digitization Commission 2016; Scaramuzzino 2019; Jacobsson \& Martinell Barfoed 2019). There is currently much talk about e-governance and about how both the social services and schools should be more available to target groups and the public, not least through digital media. Based on the results of this survey study, changes in the form of interaction with target groups and the general public could result in professionals receiving hate, threats and harassment through new communication channels. Organisations must be prepared for this. However, these results require further research, for example, by looking at the extent to which different degrees of digitalisation in the workplace correlate to people being subjected to workplace violence.

This study also shows how the fear of being exposed to hate, threats and harassment affects the autonomy and discretion of professionals. We know that a fear of being subjected to hate, threats and harassment can have serious consequences for individuals and can cause stress and burn out. However, according to the results presented in this article it can also result in self-censorship, thereby limiting autonomy and professional discretion. Even if the survey data do not provide any insights into how social workers, teachers and journalists have changed their way of working (or whether they did this reluctantly or willingly), the results provide an alarming picture of the level of this fear, as well as some of its implications. In fact, $40 \%$ of the respondents had considered stopping working on a specific social problem/topic/target group/task due to their fear of being exposed to workplace violence. As discussed by Waddington, Badger and Bull (2006), it is important not to create a "moral panic". However, these results are also worrying and suggest that a large share within these groups of professionals are too afraid to do their work and, as a consequence, limit their own professional discretion.

The results also suggest that there is a link between being digitally exposed to hate, threats and harassment and limitations in autonomy and professional discretion. This is particularly relevant in the case of journalists. This professional group is generally not subjected to workplace violence the most regarding general exposure, frequency or threats being carried out. However, they are subjected to the most digital hate, threats, and harassment, while also being the professional group that changed its way of working the most and also stopped working on specific topics. It is possible that the specific role of journalists in today's society makes them particularly vulnerable, not least because of their uncertain employment situation and the need to constantly interact with their audience via the internet and social media. Another possible expla- 
nation is that there is increased awareness of workplace violence today, for example, by trade unions.

This article also provides important theoretical insights that should be further developed. Theories on the autonomy and discretion of welfare professionals tend to focus on their "social rights role" and how excessive professional discretion can be a threat to democracy (Molander, Grimen \& Eriksen 2012; Fitzpatrick, McKeever \& Simpson 2019). However, the fear of being exposed to workplace violence can also limit their professional discretion and autonomy in deciding and acting according to their own expertise and judgment, thereby restricting their democratic role. Previous theories on the autonomy and discretion of welfare professionals have primarily focused on how external control such as laws, regulations and economic measures can restrict both autonomy and discretion. However, these theories have largely ignored how hate, threats and harassment from target groups, colleagues and managers can operate as a form of external control that could restrict a professional's autonomy on an individual level, but might also affect it on a collective level. It is important to emphasise that it is not only journalists who are subjected to such external control (Löfgren Nilsson \& Örnebring 2016) but also other professional groups such as social workers and teachers which, according to the results of this study, appear to be more at risk of leaving their jobs due to their fear of being exposed to hate, threats or harassment.

Further research that distinguishes between the different types of perpetrators is necessary. Workplace violence can originate from both within and outside an organisation - and can have different aims. Hate, threats and harassment can be the consequence of, for example, frustration due to a sense of powerlessness in the face of a professional's authority but can also be used as a strategy for silencing social workers, teachers and journalists or make them change a decision (see also Scaramuzzino forthcoming). One potential way of preventing certain forms of workplace violence could be to create better conditions for individuals and groups to constructively express their opinions and be given the opportunity to complain about the work and decisions of these professional groups. Due to the democratic role of the professional groups, it could be beneficial to adopt specific preventive measures that do not render the professionals inaccessible to their target groups or the general public, but that protect them from being subjected to hate, threats and harassment. The inability to adequately address this problem could also result in a significant reduction in skills for the organisations that employ these professional groups.

As suggested by Waddington, Badger and Bull (2006:183), there is probably no "quick fix" solution to this problem, and probably not the same kind of "fix" for the three professional groups. However, it is important to acknowledge the consequences of hate, threats and harassment against professional groups that play a democratic role, and that these professionals do not feel that they have to "stand alone" when dealing with workplace violence. 


\section{Funding}

This work was supported by the Swedish Research Council for Health, Working Life and Welfare [Forte], grant number 2017-01153.

\section{References}

AFA Insurance [AFA Försäkringar] (2018a) "Hot och våld på den svenska arbetsmarknaden”. Report December 2018. https://www.afaforsakring.se/globalassets/ nyhetsrum/seminarier/hot-och-vald-pa-den-svenska-arbetsmarknaden/f6345-delrapport-4---hotovald.pdf (Accessed 3 December 2020).

AFA Insurance [AFA Försäkringar] (2018b) "Hot och våld i kommun- och landstingssektorn”. Report January 2018. https://www.afaforsakring.se/globalassets/forebyggande/ analys-och-statistik/arbetsskaderapporten/ovriga-rapporter-om-arbetsskador-ochsjukfranvaro/minirapport_hot-och-vald.pdf (Accessed 3 December 2020).

Almond, P. \& G.C. Gray (2016) "Frontline safety: Understanding the workplace as a site of regulatory engagement”, Law \& Policy 39 (1):5-26. https://doi.org/10.1111/ lapo. 12070

Brodkin, E.Z. (2020) "Discretion in the welfare state", 63-78 in T. Evans \& P. Hupe (Eds.) Discretion and the quest for controlled freedom. London: Palgrave Macmillan. https://doi.org/10.1007/978-3-030-19566-3_5

Cole, L.L., P. Grubb, S.L. Sauter, N.G. Swanson \& P. Lawless (1997) "Psychosocial correlates of harassment, threats and fear of violence in the workplace", Scandinavian Journal of Work, Environment \& Health 23 (6):450-457. https://doi.org/10.5271/ sjweh.268

Crawford, A. \& S. Hutchinson (2015) "Mapping the contours of 'everyday security': Time, space and emotion”, British Journal of Criminology 56 (6):1184-1202. https:// doi.org/10.1093/bjc/azv121

Digitization Commission [Digitaliseringskommissionen] (2016) För digitalisering i tiden: Slutbetänkande av Digitaliseringskommissionen [For digitization in time: Final report by the Digitization Commission]. SOU 2016:89. Stockholm: Wolters Kluwers.

Eggebø, H. \& E. Stubberud (2016) Hatefulle ytringer. Delrapport 2: Forskning på hat og diskriminering. Rapport 2016:15. Oslo: Institute for Social Research.

Evans, T. (2020) "Discretion and professional work", 357-375 in T. Evans \& P. Hupe (Eds.) Discretion and the quest for controlled freedom. London: Palgrave Macmillan. https://doi.org/10.1007/978-3-030-19566-3_23

Evans, T. (2013) "Organisational rules and discretion in adult social work", British Journal of Social Work 43 (4):739-758. https://doi.org/10.1093/bjsw/bcs008

Evetts, J. (2002) "New directions in state and international professional occupations: Discretionary decision-making and acquired regulation”, Work, Employment and Society 16 (2):341-353. https://doi.org/10.1177/095001702400426875 
Fitzpatrick, C., G. McKeever \& M. Simpson (2019) "Conditionality, discretion and TH Marshall's 'right to welfare", Journal of Social Welfare and Family Law 41 (4):445-462. https://doi.org/10.1080/09649069.2019.1663016

Forssell, R. (2016) "Exploring cyberbullying and face-to-face bullying in working life: Prevalence, targets and expressions”, Computers in Human Behavior 58: 454-460. https://doi.org/10.1016/j.chb.2016.01.003

Freidson, E. (1994) Professionalism reborn: Theory, prophecy and policy. Oxford: Polity Press.

Frenzel, A. (2017) Politikernas trygghetsundersökning 2017: Förtroendevaldas utsatthet och oro för trakasserier, hot och våld 2016. Rapport 2017:9. Stockholm: The Swedish National Council for Crime Prevention.

Fynboe, E.J., L. Huibers, B. Christensen \& M. Bondo (2018) "Paper- or web-based questionnaire invitations as a method for data collection: Cross-sectional comparative study of differences in response rate, completeness of data, and financial cost", Journal of Medical Internet Research 20 (1):e24. https://doi.org/10.2196/ jmir. 8353

Göransson, S., R. Knight, J. Guthenberg \& M. Sverke (2011) Hot och våld i skolan: En enkätstudie bland lärare och elever. Kunskapsöversikt. Rapport 2011:15 [Threats and violence in school: A survey study among teachers and pupils. A knowledge overview]. The Swedish Work Environment Authority.

Heiskanen, M. (2007) "Violence at work in Finland: Trends, contents, and prevention", Journal of Scandinavian Studies in Criminology and Crime Prevention 8 (1): 22-40. https://doi.org/10.1080/14043850701278473

Hughes, S. \& M. Márquez-Ramírez (2018) “Local-level authoritarianism, democratic normative aspirations, and antipress harassment: Predictors of threats to journalists in Mexico", The International Journal of Press/Politics 23 (4):539-560. https://doi. org/10.1177/1940161218786041

Human Rights Watch (2010) “Their future is at stake”: Attacks on teachers and schools in Pakistan's Balochistan province. New York: Human Rights Watch.

Jacobsson, K. \& E. Martinell Barfoed (2019) Socialt arbete och pappersgöra: Mellan klient och digitala dokument. Malmö: Gleerups.

Jerre, K. (2009) "Ökat hot och våld i arbetslivet - en följd av förändrade arbetsförhållanden?: En studie utifrån de svenska Arbetsmiljöundersökningarna 1991-2005”, Sociologisk Forskning 46 (1):67-89.

Journalistpanelen (2016) “Hoten och hatet mot journalister”. Newsletter May 2016. Gothenburg: The Department of Journalism, Media and Communication, University of Gothenburg.

Kargar, S. \& A. Rauchfleisch (2019) "State-aligned trolling in Iran and the doubleedged affordances of Instagram”, New Media \& Society 21 (7):1506-1527. https:// doi.org/10.1177/1461444818825133

Koritsas, S., J. Coles \& M. Boyle (2010) "Workplace violence towards social workers: The Australian experience”, British Journal of Social Work 40 (1):257-271. https:// doi.org/10.1093/bjsw/bcn134 
Lundquist, L. (1998) Demokratins väktare: Ämbetsmännen och vårt offentliga etos. Lund: Studentlitteratur.

Löfgren Nilsson, M. (2015) "Hot och hat mot svenska journalister", Nordicom Information 37 (3-4):51-56.

Löfgren Nilsson, M. (2017) Journalisternas trygghetsundersökning: Journalisters utsatthet under 2016. Working paper no. 75. Gothenburg: The Department of Journalism, Media and Communication, University of Gothenburg.

Löfgren Nilsson, M. \& H. Örnebring (2016) “Journalism under threat: Intimidation and harassment of Swedish journalists", Journalism Practice 10 (7):880-890. https:// doi.org/10.1080/17512786.2016.1164614

Molander, A., H. Grimen \& E.O. Eriksen (2012) "Professional discretion and accountability in the welfare state”, Journal of Applied Philosophy 29 (3):214-230. https:// doi.org/10.1111/j.1468-5930.2012.00564.x

Muhonen, T., S. Jönsson \& M. Bäckström (2017) "Consequences of cyberbullying behaviour in working life: The mediating roles of social support and social organisational climate", International Journal of Workplace Health Management 10 (5):376-390. https://doi.org/10.1108/ijwhm-10-2016-0075

Novus \& Union for Professionals [Akademikerförbundet SSR] (2016) "Kartläggning socialsekreterare”, https://akademssr.se/sites/default/files/files/novus_socialsekr_2016_pdf.pdf (Accessed 4 December 2020).

Patel, E. \& S. Holmberg (2015) Hot och våld: Om utsatthet i yrkesgrupper som är viktiga $i$ det demokratiska sambället. Rapport 2015:12. Stockholm: The Swedish National Council for Crime Prevention.

Rayner, C. \& C. Cooper (2006) "Workplace bullying”, 121-146 in K.E. Kelloway, J. Barling \& J.J. Hurrell Jr (Eds.) Handbook of workplace violence. Thousand Oaks: SAGE. https://doi.org/10.4135/9781412976947.n7

Respass, G. \& B.K. Payne (2008) "Social services workers and workplace violence”, Journal of Aggression, Maltreatment \& Trauma 16 (2):131-143. https://doi. org/10.1080/10926770801921287

Scaramuzzino, G. (2019) "Socialarbetare om automatisering i socialt arbete: En webbenkätundersökning”. Research Reports in Social Work 2019 (3). Lund: School of Social Work, Lund University.

Scaramuzzino, G. \& R. Scaramuzzino (forthcoming) "Hat, hot och kränkningar mot ledare i civilsamhället: Politisk, rumslig och personlig kontroll av civilsamhällets röst-funktion”. Unpublished manuscript.

Scaramuzzino, G. (forthcoming) "Powerful and vulnerable: Workplace violence against Swedish social workers, teachers, and journalists”. Unpublished manuscript.

Shier, M.L., R.J. Graham \& D. Nicholas (2018) "Interpersonal interactions, workplace violence, and occupational health outcomes among social workers", Journal of Social Work 8 (5):525-547. https://doi.org/10.1177/1468017316656089

Svensson, K., E. Johnsson \& L. Laanemets (2008) Handlingsutrymme: Utmaningar $i$ socialt arbete. Stockholm: Natur \& Kultur. 
Swedish Union of Journalists [Svenska Journalistförbundet] (2009) "Våld och hot mot journalister: En rapport från Svenska Journalistförbundet".

Swedish Union of Journalists [Svenska Journalistförbundet] (2019) “About us", https:// www.sjf.se/om-journalistforbundet (Accessed 30 December 2019).

Swedish Teachers' Union [Lärarförbundet] (2019) "Welcome to Lärarförbundet", https://www.lararforbundet.se/artiklar/welcome-to-lararforbundet (Accessed 30 December 2019).

Swedish Work Environment Authority [Arbetsmiljöverket] (2018) "Projektrapport 'Socialsekreterares arbetsmiljö”. Report 2015/051465. https://www.av.se/globalassets/ filer/publikationer/rapporter/slutrapport-socialsekreterares-arbetsmiljo.pdf (Accessed 3 December 2020).

Tandoc, E.C. Jr. (2017) "Watching over the watchdogs: The problems that Filipino journalists face”, Journalism Studies 18 (1):102-117. https://doi.org/10.1080/14616 70x.2016.1218298

Union for Professionals [Akademikerförbundet SSR] (2019) "The Union for Professionals - the voice for academics”, https://akademssr.se/english (Accessed 30 December 2019).

Waddington, P.A.J., D. Badger \& R. Bull (2005) "Appraising the inclusive definition of workplace 'violence”, The British Journal of Criminology 45 (2):141-164. https:// doi.org/10.1093/bjc/azh052

Waddington, P.A.J., D. Badger \& R. Bull (2006) The violent workplace. London: Willan Publishing. https://doi.org/10.4324/9781843926900

Wallström, K., L. Korsell \& R.E. Andersson (2009) Motverka otillàten påverkan: En handbok för myndigheter om att förebygga trakasserier, hot, vald och korruption. Stockholm: The Swedish National Council for Crime Prevention.

Waisbord, S. (2013) Reinventing professionalism: Journalism and news in global perspective. Cambridge: Polity.

Wikman, S. (2016) "Varför ökar det arbetsrelaterade våldet?", Arbetsmarknad \& Arbetsliv $22(2): 49-66$.

Wikman, S., \& U. Rickfors (2017) Att förebygga hot och våld $i$ statliga myndigheter: En jämförelse mellan två perspektiv på säkerhetsarbete. Lund: Design Sciences, Lund University.

Winstanley, S. \& L. Hales (2015) "A preliminary study of burnout in residential social workers experiencing workplace aggression: Might it be cyclical?”, British Journal of Social Work 45 (1):24-33. https://doi.org/10.1093/bjsw/bcu036

Yesil, M.M. (2014) "The invisible threat for the future of journalism: Self-censorship and conflicting interests in an increasingly competitive media environment", International Journal of Business and Social Science 5 (3):71-78. 


\title{
Appendix
}

Table 9. Research questions, survey questions and response alternatives

\begin{tabular}{|c|c|c|}
\hline Research questions & Survey questions & Response alternatives \\
\hline \multirow[t]{3}{*}{ RQ1 } & $\begin{array}{l}\text { Have you ever been exposed to hate, threats } \\
\text { or harassment in your professional role? }\end{array}$ & yes; no \\
\hline & $\begin{array}{l}\text { Over the last two years, how often have you } \\
\text { been subjected to hate, threats or harass- } \\
\text { ment in your professional role? }\end{array}$ & $\begin{array}{l}\text { never; sometimes every six } \\
\text { months; sometimes once } \\
\text { a month; sometime once a } \\
\text { week; every day }\end{array}$ \\
\hline & $\begin{array}{l}\text { Over the last two years, have the threats you } \\
\text { received been carried out? }\end{array}$ & $\begin{array}{l}\text { yes, often or always; yes, } \\
\text { sometimes; yes, but rarely; } \\
\text { no, never }\end{array}$ \\
\hline RQ2 & $\begin{array}{l}\text { Over the last two years, where and how did } \\
\text { you receive hate, threats or harassment? } \\
\text { (face to face, Phone/SMS/MMS, internet } \\
\text { and social media). }\end{array}$ & yes; no \\
\hline \multirow[t]{3}{*}{ RQ3 } & $\begin{array}{l}\text { Have you ever changed your way of working } \\
\text { due to your fear of being exposed to hate, } \\
\text { threats or harassment? }\end{array}$ & yes; no \\
\hline & $\begin{array}{l}\text { Have you ever considered stopping working } \\
\text { on a specific social problem (social workers), } \\
\text { topic (teachers, journalists), target group } \\
\text { task (social workers, teachers, journalists) } \\
\text { due to your fear of being exposed to hate, } \\
\text { threats or harassment? }\end{array}$ & yes; no \\
\hline & $\begin{array}{l}\text { Have you ever considered leaving your job } \\
\text { due to your fear of being exposed to hate, } \\
\text { threats or harassment? }\end{array}$ & yes; no \\
\hline
\end{tabular}

\begin{abstract}
Author
Gabriella Scaramuzzino is a researcher at Lund University, Sweden. Her research interests concern how the use of social media affects society in different ways. In an ongoing research project, she explores how the fear of being subjected to hate, threats and harassment affects social workers, teachers and journalists, as well as people active in civil society.
\end{abstract}

\section{Corresponding author}

Gabriella Scaramuzzino

School of Social Work, Lund University

Box 23, 22100 Lund, Sweden

gabriella.scaramuzzino@soch.lu.se 